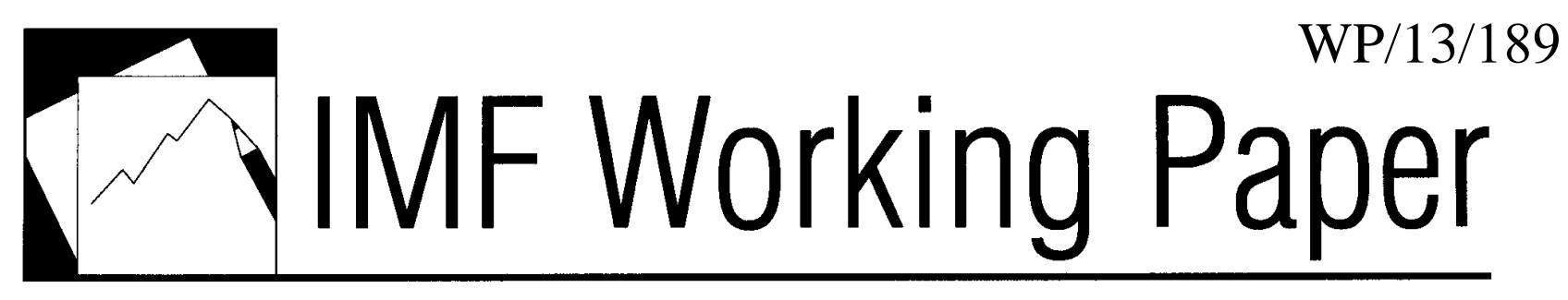

\title{
Do Inflows or Outflows Dominate? Global Implications of Capital Account Liberalization in China
}

Tamim Bayoumi and Franziska Ohnsorge 


\title{
IMF Working Paper
}

Strategy, Policy, and Review Department (SPR)

\section{Do Inflows or Outflows Dominate? Global Implications of Capital Account Liberalization in China}

\section{Prepared by Tamim Bayoumi and Franziska Ohnsorge}

August 2013

\section{This Working Paper should not be reported as representing the views of the IMF.} The views expressed in this Working Paper are those of the author(s) and do not necessarily represent those of the IMF or IMF policy. Working Papers describe research in progress by the author(s) and are published to elicit comments and to further debate.

\begin{abstract}
This paper assesses the implications of Chinese capital account liberalization for capital flows. Stylized facts from capital account liberalization in advanced and large emerging market economies illustrate that capital account liberalization has historically generated large gross capital in- and outflows, but the direction of net flows has depended on many factors. An econometric portfolio allocation model finds that capital controls significantly dampen cross-border portfolio asset holdings. The model also suggests that capital account liberalization in China may trigger net portfolio outflows as large domestic savings seek to diversify abroad.
\end{abstract}

JEL Classification Numbers: F2; F3; F4; F6; G1

Keywords: Capital account liberalization; portfolio flows; capital flows; financial development Author’s E-Mail Address: tbayoumi@imforg; fohnsorge@imf.org 
I. Introduction 3

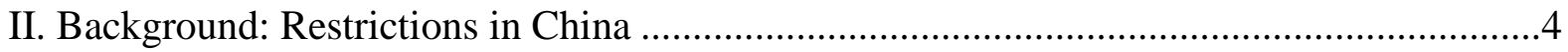

III. Stylized Facts: Capital Account Liberalization Episodes since the 1970s .......................6

IV. Estimating the possible impact of capital account liberalization...................................

V. Implications for China and Conclusions ............................................................. 14

Boxes

1. Country Examples of Capital Account Liberalization.................................................18

2. U.K. Removal of Exchange Controls in 1979-80 .....................................................19

3. Japan. Removal of Exchange Controls in 197980 .....................................................20

Figures

1. Change in Net Financial Flows and Business Cycle at Time of Liberalization ...................8

Tables

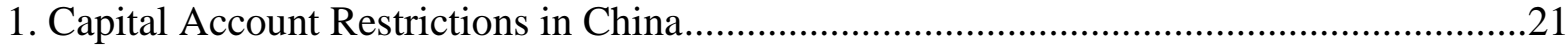

2. Capital Account Restrictions ....................................................................................2 23

3. FGLS Regression: Share of Bilateral Portfolio assets in Total Portfolio, 2005-10 ...........24

4. FGLS Regression: Share of Bilateral Portfolio Assets in Total Portfolio, 2005-10 ...........25

5. Panel Regression: Share of Bilateral Portfolio assets in Total Portfolio, 2005-10 ............26

6. FGLS Regression: Share of Bilateral Portfolio Assets in Total Portfolio, 2005-10 ..........27

7. Impact of Hypothetical Capital Account Liberalization in China ....................................28

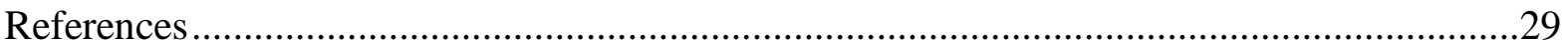




\section{INTRODUCTION}

China's $12^{\text {th }}$ Five-Year Plan pledges to accelerate capital account liberalization. This would be a major event in the global financial architecture. Despite steps to ease restrictions and some circumvention over the past decade, much of China's capital account and, especially, portfolio investment flows remain severely restricted - as can be seen from various crosscountry indexes of capital controls (Bayoumi and Sabroski, 2012, Table 2). ${ }^{1}$ Accordingly, this paper looks into the potential consequences of a full opening of China's capital markets. We do this by estimating an empirical model that relates the level of gross bilateral international assets and liabilities between a wide range of countries to fundamentals, including the level of capital controls. We then use the results to infer the potential portfolio in- and outflows that might follow liberalization of the Chinese capital account. We find that gross flows both into and out of China would be substantial and that the likely direction of net flows would be outflows. Our estimated orders of magnitude would imply significant repercussions for both Chinese and global financial markets. ${ }^{2}$

Previous authors have also estimated potential capital flows if China liberalizes its capital account and have found broadly similar results. In a study that this paper builds on but that is limited to U.S. financial markets, Forbes (2010) estimates that capital account opening could raise Chinese exposures to U.S. equity markets by almost half. Based on the experience of 37 developing and emerging markets that liberalized since the mid-1990s, Sedik and Sun (2012) estimate that inflows and outflows could rise by 2-31/4 percentage points of GDP between 2012 and 2016, and outflows would increase by more than inflows. Based on a dynamic panel estimation of portfolio and FDI asset and liability flows in advanced or emerging markets, He and others (2012) estimate that capital account opening could generate a stock adjustment in international portfolio assets and liabilities of 21 and 16 percent of GDP, respectively, by 2020 and in direct investment assets and liabilities of 22 and 11 percent of GDP, respectively. ${ }^{3}$

The following section describes the main Chinese capital controls. Section III recaps briefly the experience of other advanced and emerging market countries that have opened their

\footnotetext{
${ }^{1}$ That said, realization cannot be assured. A pledge for full convertibility by 2000 was made in 1993 but its implementation was delayed after the Asian financial crisis.

${ }^{2}$ Of course, our exercise implicitly assumes that inferences drawn from our sample are applicable to China. Also, ours is a partial equilibrium exercise. The existing set of very large and complementary distortions makes it difficult to contemplate removal of any one distortion in particular. Effects of the order of magnitude projected here could well generate offsetting general equilibrium effects that dampen the overall impact of liberalization but would go beyond the scope of this paper.

${ }^{3} \mathrm{He}$ and others (2012) discuss the difficulties in identifying the determinants of other investment flows, where inconclusive results are found based on panel regression analysis.
} 
capital accounts since the 1970s. Section IV presents the econometric results and Section V concludes with some implications of the econometric results.

\section{BACKGROUND: RESTRICTIONS IN CHINA}

China has gradually been opening its capital account, but capital flows remain subject to considerable restrictions. There are at least three categorizations of capital account openness: Quinn (2003) for capital and current accounts; Chinn and Ito (2008) for FDI and non-FDI financial accounts; and Schindler (2009) for detailed capital account categories. Schindler (2009) has proposed a classification of capital controls based on the main categories of capital flows in the balance of payments: FDI, equity and bond flows; flows through collective investment vehicles (e.g., ETFs or mutual funds); and foreign borrowing. Of course, these measures are indices of the existence of restrictions, not their intensity. They would not Capital account restrictions

\begin{tabular}{l}
\hline \\
SCHINDLER financial account restrictions (2010) 1/ \\
Overall inflow restrictions index \\
Overall outflow restrictions index \\
Overall non-FDI financial account restrictions index \\
QUINN capital and financial account openness (2011) 2/ \\
Capital outflows/residents \\
Capital inflows/nonresidents \\
CHINN-ITO openness (2010) 3/ \\
Source: Schindler (2009); Quinn (1997); Chinn and Ito (2007). \\
1/ Includes ratings for FDI which are not shown here. 1 indicates a restriction that goes beyond \\
registration and notifaction requirements. \\
2/ Quinn (1997) index takes into account intensity of restrictions on a scale of 0, 0.5, 1, 1.5, and 2. \\
Capital restrictions include FDI and nonFDI. \\
3/ Chinn-Ito (2007) index is principal component of four 0-1 subindices on average over 5 years. \\
Index refers to current account and financial account restrictions.
\end{tabular}
capture a relaxation (as opposed to elimination) of existing controls, e.g., by increasing quotas. Bearing in mind this caveat, every category of flow-whether by residents or nonresidents, inflows or outflows - retains some approval requirement or quota in China (Table 1). By comparison with other emerging markets, the existence of restrictions remain pervasive (Table 2). Specifically:

- FDI. Inward FDI and its liquidation remain subject to approval requirements in several areas (Table 1).

- Portfolio investment is controlled by quotas. Inward investment is channeled through Qualified Foreign Institutional Investors (QFII), subject to a 3-month lock-in period for most shares, and an aggregate ceiling of US $\$ 150$ billion (since July 2013). In 2011, an R-QFII scheme was introduced that allows qualified firms to invest offshore renminbi back into China, subject to an overall ceiling that was raised to renminbi 270 billion by end-2012. Outward portfolio investment - for foreign securities purchased by residents - is channeled through Qualified Domestic Institutional

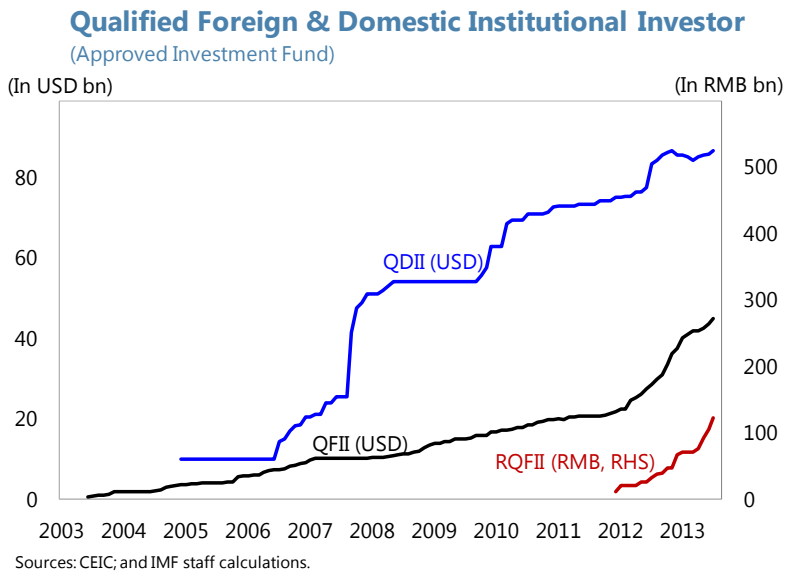


Investors (QDII), subject to institution-specific ceilings that amounted to US\$86 billion by end-2012. Cross-border issuance of securities requires approval.

- Other investment. Foreign borrowing is subject to a ceiling (for short-term borrowing) or approval requirements (for long-term borrowing), but lending abroad is largely unrestricted. The holding of cross-border accounts requires SAFE approval.

Despite these restrictions, there are substantial non-FDI capital flows into and out of China. In particular, "other" investment flows are similar in absolute magnitude to those of a fully liberalized country such as Australia. These other investment flows include the buildup or drawdown of foreign currency deposits at domestic banks. These deposits have tended to fluctuate with exchange rate expectations (Ma and McCauley, 2003) as state-owned enterprises have adjusted their profit repatriation. Many capital flows also pass through the current account. Li (2008) estimated capital flows through misinvoicing of trade flows on the order of 5.55.9 percent of GDP in 2007.
Capital flows, average 2005-2010 (percent of GDP)

\begin{tabular}{|c|c|c|c|c|c|c|c|c|c|c|}
\hline & 胥 & $\frac{\frac{\pi}{4}}{\frac{\pi}{\pi}}$ & $\begin{array}{l}\dddot{\Xi} \\
\stackrel{0}{0} \\
\end{array}$ & $\begin{array}{l}\overline{\mathbb{N}} \\
\text { 心 } \\
\end{array}$ & 옹 & $\begin{array}{l}\text { D } \\
\frac{\pi}{0} \\
0\end{array}$ & 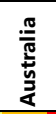 & 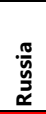 & 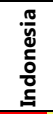 & 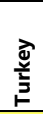 \\
\hline Financial account & 3.0 & 8.0 & 0.0 & 2.9 & 4.2 & 5.4 & -5.1 & 0.8 & 0.9 & 5.3 \\
\hline Overall non-FDI capital account & -0.2 & 6.5 & 1.3 & 1.6 & 3.2 & 3.5 & -3.9 & 1.0 & 0.0 & 2.9 \\
\hline FDI & 3.2 & 1.5 & -1.4 & 1.3 & 1.0 & 1.9 & -1.3 & -0.2 & 0.9 & 2.4 \\
\hline Inflow & 4.0 & 4.7 & 0.3 & 2.1 & 2.2 & 3.0 & 1.3 & 3.0 & 1.8 & -0.3 \\
\hline Outflow & -0.8 & 3.2 & -1.7 & $-0.8-2$ & -1.2 & -1.1 & 2.6 & 3.2 & -0.8 & 1.0 \\
\hline Portfolio investment & -0.1 & 0.4 & 0.8 & 1.8 & 1.3 & 1.3 & -4.2 & 0.3 & 1.3 & 0.0 \\
\hline Average equity & 0.5 & 2.3 & -1.9 & 1.2 & & .. & 0.8 & -0.1 & & 0.0 \\
\hline Average bond & -0.5 & -0.5 & 1.8 & 0.7 & & & -5.0 & 0.4 & & 0.4 \\
\hline Other investment & -0.1 & 6.2 & 0.6 & -0.3 & 1.9 & 2.2 & 0.3 & 0.7 & -1.3 & 2.9 \\
\hline Average financial credit & -0.1 & 6.2 & 0.6 & -0.3 & 1.9 & 2.2 & 0.3 & 0.7 & -1.3 & 2.9 \\
\hline Liabilities & 1.8 & 1.1 & 1.5 & 0.9 & 1.0 & -0.1 & -1.9 & -3.6 & & 2.9 \\
\hline Assets & -1.9 & 4.9 & -0.9 & -1.1 & 0.9 & 2.3 & 2.2 & 4.3 & & 0.0 \\
\hline \multicolumn{11}{|c|}{ International investment position: Portfolio and other investment } \\
\hline Assets & 15 & 30 & 21 & 6 & 1 & 9 & 47 & 17 & 4 & 10 \\
\hline Liabilities & 16 & 64 & 60 & 33 & 24 & 54 & 95 & 36 & 32 & 46 \\
\hline \multicolumn{11}{|c|}{ Source: Haver Analytics; IMF IFS; staff estimates. } \\
\hline \multicolumn{11}{|c|}{$\begin{array}{l}\text { Note: Colours reflect the quartile of absolute values in each row, with red the lowest } \\
\text { quartile and yellow the highest quartile. Data for Australia, Russia, Malaysia based on } \\
\text { BPM6. For all others based on BPM5. }\end{array}$} \\
\hline
\end{tabular}

As China's authorities speed up steps to open the capital account, historical experience in other countries serves as caution. Capital account liberalization has historically often been followed by exchange rate or banking crises (Box 1). That said, the link is not always as close as is sometimes protrayed. For example, the financial crises in the U.K. and Japan occurred about a decade after capital account liberalization and that in Denmark two decades later.

Several authors have explored the preconditions for "safe" capital account liberalization and have concluded that they are not yet fulfilled in China. Since Fischer (1998), the preconditions for successful capital account liberalization have generally been accepted to be a stable macroeconomic environment, a sound banking system, and developed financial markets. Already in 2001, Groomberg (2001) listed weak SOEs and banks as well as underdeveloped capital markets as risk factors in capital account liberalization for China. ${ }^{4}$ Most recently, Lardy (2011) also argued that the preconditions for ${ }^{4}$ However, Groomberg (2001) also called for capital account liberalization to provide a new reform impulse.

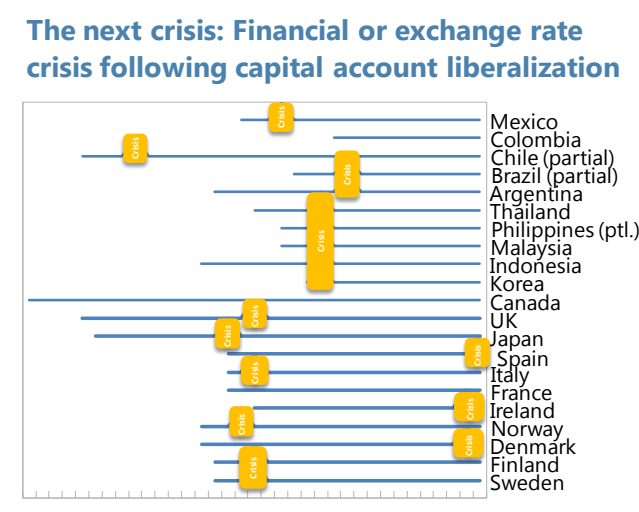

197519791983198719911995199920032007

Sources: Kaminsky and Schmukler (2003), IMF (2012). 
"safe" capital account liberalization have not yet been fulfilled: without interest rate liberalization it is difficult to assess the soundness of the financial system; parts of the Chinese financial system, and especially the corporate bond market, are profoundly underdeveloped; and the exchange rate remains undervalued. Whether conditions are in place for smooth capital account opening, is a question that is beyond the scope of this paper.

\section{Stylized Facts: Capital ACCOUnt Liberalization Episodes Since The 1970S}

Kaminsky and Schmukler (2003) have compiled a database that dates full or partial capital account, financial sector, and stock market liberalization. These dates are used to compare changes in portfolio and other investment capital flows (in percent of GDP) before and after liberalization.

Following liberalization, gross capital flows generally increased substantially. For example, capital account liberalization was followed by a buildup of gross international assets over the subsequent five years of some 60 percent of GDP in the United Kingdom (1979) and about half that amount in Chile (1992) and Italy (1992).

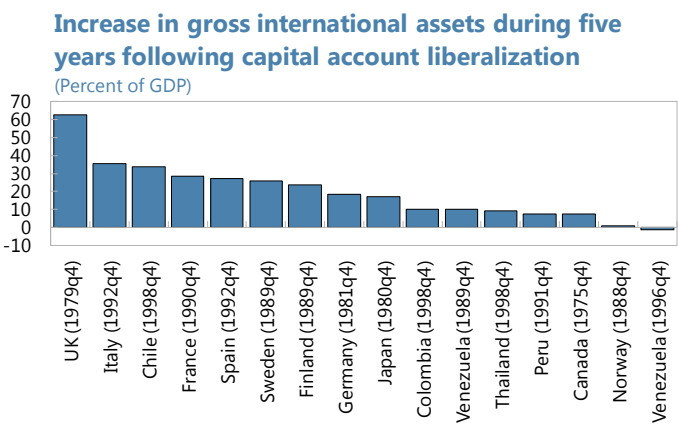

The direction of net capital flows after liberalization, however, depended on many factors. Sources: IMF IFS. Note: Data for UK only available for year after capital account liberalization. Prasad and Rajan (2008) point to a plethora of nonlinearities and threshold effects that make predictions about the eventual impact of capital account liberalization unreliable. For example, capital account liberalization was followed by substantial net portfolio and other investment outflows in Sweden, Finland, and Spain, but inflows in Denmark, Chile, and Colombia.

Here we focus on four factors that could determine net flows: the domestic and global business cycle, the sequencing of ancillary reforms, and growth prospects. For each country a bilateral trade-weighted average real GDP growth of 12 of the largest economies is defined as "world" growth. ${ }^{5}$ For both domestic and world real GDP growth, business cycle peaks and troughs at least four quarters apart are identified using the algorithm of Harding and Pagan (2002). A country's or the world's position in the business cycle is described by a variable that is the fraction of an upswing underway (positive) or the fraction of a downswing

\footnotetext{
${ }^{5}$ These economies are the U.S., Japan, the U.K., Germany, France, Italy, Canada, Norway, Sweden, Finland, Spain, Korea, and Argentina. These are the countries for which a continuous time series is available since the 1970s.
} 
underway (negative). ${ }^{6}$ Since data on both business cycles and capital flows is only available for some 16-21 countries, regression estimation is of doubtful value. However, there are a few correlations that are noticeable in scatter plots; especially for the relationship between net other investment flows and domestic growth and the relationship between portfolio investment flows and world growth and financial sector liberalization.

- $\quad$ Domestic business cycle: Figure 1a shows the business cycle position at the time of capital account liberalization against the change in net other investment inflows (in percent of GDP) between the year following liberalization and the year preceding it. Typically, the more advanced a domestic upswing, the greater the net outflows. ${ }^{7}$ This may have reflected residents seeking to diversify their domestic financial assets in upswings and borrowing in downswings.

- $\quad$ Growth prospects: Figure 1b shows the correlation between average annual growth in the ten years following capital account liberalization (a proxy for growth prospects) and the change in net other investment inflows between the years following and preceding liberalization. Net inflows increased more in countries with higher growth prospects.

\footnotetext{
${ }^{6} \mathrm{~A}$ positive business cycle variable indicates the share of quarters since the last business cycle trough in the total number of quarters between the last trough and next peak. A negative business cycle variable indicates the share of quarters since the last business cycle peak in the total number of quarters between the last peak and next trough.

${ }^{7}$ In contrast, the relationship between net inflows and the domestic business cycle seems to be nonlinear. There have been net outflows both when the domestic business cycle emerged from a trough and when it had reached a peak.
} 
Figure 1. Change in Net Financial Flows and Business Cycle at Time of Capital Account Liberalization
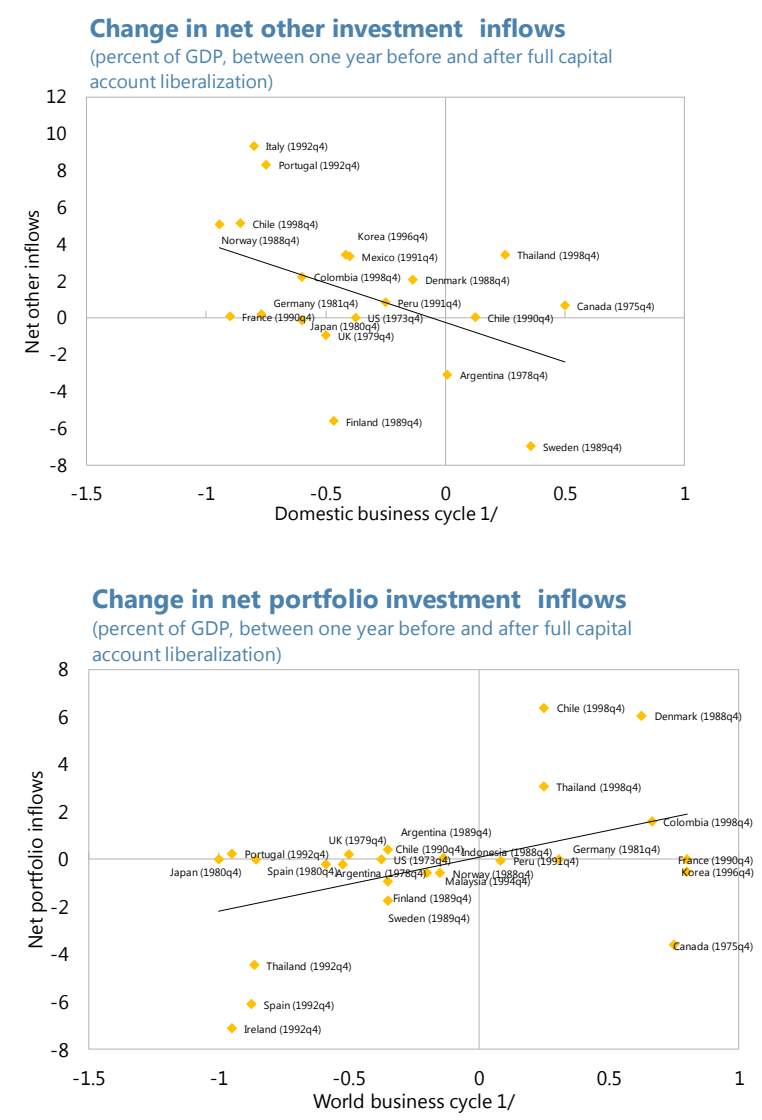
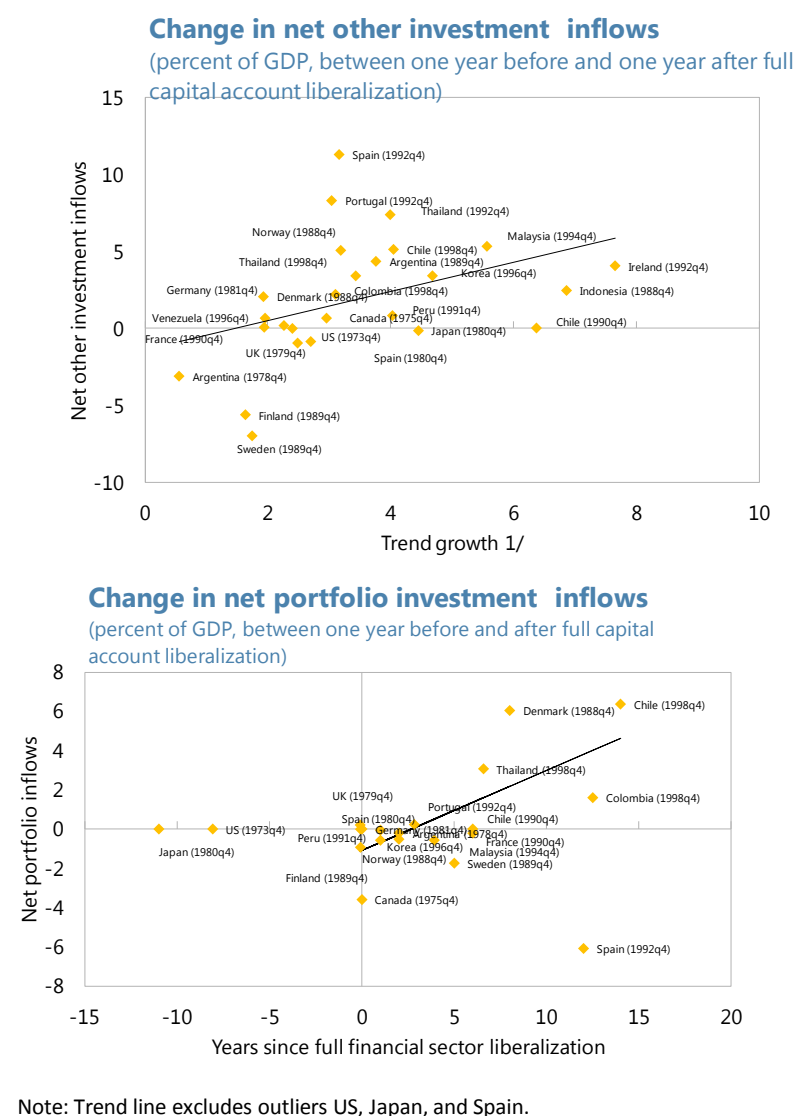

1/Business cycle defined as share of real GDP growth upturn completed from trough to peak (+) or share of downturn completed from peak to trough (-). Peak and trough dated using Harding-Pagan (2002) algorithm. Timing of financial sector and capital account liberalization as in Kaminsky and Schmukler (2003).

$2 /$ Trend growth is defined as real GDP growth over the ten years following capital account liberalization.

- $\quad$ World business cycle: Figure 1c shows a similar plot to Figure 1a, of the world business cycle position at the time of capital account liberalization and the change in net portfolio investment inflows. A more advanced upswing in the world business cycle typically increased net portfolio inflows. This may reflect inflows from nonresidents seeking to diversify their securities exposures when the global business growth is buoyant and investor sentiment sanguine.

- $\quad$ Financial sector liberalization: Figure 1d plots the number of years from financial sector liberalization to capital account liberalization (both dated as in Kaminsky and Schmukler, 2003) against the change in net inflows of portfolio investment (in percent of GDP) in the year following liberalization and the year preceding it. In general, the more recent financial repression, the greater net outflows in portfolio investment tended to be. In contrast, in Japan and the United States, where capital account liberalization preceded financial sector liberalization by several years, net inflows were negligible after capital account liberalization. 
The experiences of capital account liberalization in the U.K. and Japan in 1979 and 1980, respectively, serve as contrasting examples. The U.K. (Box 2) liberalized its capital account in 1979 and removed remaining financial sector restrictions shortly thereafter. The liberalization was followed by substantial net capital outflows in a stock adjustment that has been estimated at up to 10 percent of GDP (Taylor and Artis, 1989). ${ }^{8}$ Following two decades of alternating liberalizing and restricting measures, Japan (Box 3) eventually liberalized its capital account in 1980 but the financial sector remained heavily restricted. Capital account liberalization was initially not followed by any significant net capital flows. Financial sector liberalization only began in 1985. (Note that despite the different timing of the Japanese and U.K. financial sector liberalizations, both countries experienced a credit boom in the late 1980s and a housing market crash in 1989-90.)

\section{ESTIMATING THE POSSIBLE IMPACT OF CAPITAL ACCOUNT LIBERALIZATION}

The previous section described capital flows over a short two-year window. Such short-term flows would be motivated not only by capital account liberalization but also by short-term factors such as business cycles. A long history of capital controls, however, is likely to cause a stock adjustment that may take longer than two years and is driven by structural factors such as financial market development. This is what we explore next.

The baseline regression equation is the generalized, multi-country version of that used in Forbes (2010) for the U.S. alone: ${ }^{9}$

$$
w_{i j}=\beta_{0} w_{j}^{*}+\beta_{1} c_{i}-\left(\beta_{2} c_{i, j}-\beta_{3} c_{j}\right)
$$

where $w_{i j}$ is the share of country $i$ 's total portfolio investment that is invested in country $j, w_{j}{ }^{*}$ is country $j$ 's share in the world market portfolio, $c_{i}$ are the marginal cost of investing in country $i, c_{i j}$ are the marginal cost of an investor in country $i$ investing in country $j$, and $c_{j}$ are the marginal cost of investing in country $j$. The first term on the right hand side controls for the share of country $j$ in the global stock market portfolio. The second term captures the fact that higher cost of investing in country $i$ increase the share of portfolio investment abroad, in any country $j$.

\footnotetext{
${ }^{8}$ But note that Bank of England (1981) estimated the stock adjustment at only 0.2 percent of GDP.

${ }^{9}$ Specifically, the regression equation is based on equation (9) of Forbes (2010).
} 
The last term in brackets captures the notion that country $i$ will invest a greater share of its portfolio assets in country $j$ than the world market share if country $i$ 's cost of investing in $j$ are less than world average cost of investing in $j .{ }^{10}$

This regression specification is similar to that of Bertaut and Kole (2004) and Lane and Milesi-Ferretti (2008) but expanded to focus on capital controls which is a core variable of interest here. Capital controls are not included in the regressions reported in Bertaut and Kole (2004), only source country controls are included in the regressions reported in Lane and Milesi-Ferretti (2008) and only destination country controls in Guo (2011).

The focus on bilateral exposures mitigates some of the concerns about reverse causality with which previous studies have struggled. ${ }^{11}$ The independent country-level variables are unlikely to be driven by the dependent variable of diversified bilateral exposures to investment partner countries. The size of source country and destination country financial markets are the exception. Since they include foreign holdings, they could in principle be biased by reverse causality. We therefore include an instrumental variables regression as robustness check. Forbes (2010) highlights other econometric challenges of the regression specification above: persistence in the dependent variable that is defined as a stock variable - and hence likely autocorrelation in the error term - and heteroskedasticity in the variance across country pairs. Following Forbes, an FGLS estimation is used that allows for heteroskedasticity and countrypair-specific autocorrelation in the error term with a first-order autoregressive process.

The dependent variable, the share of country $i$ 's total portfolio investment that is invested in country $j$, is calculated using bilateral portfolio assets (equity and debt separately) reported in the IMF's CPIS database as a share of country $i$ 's total securities portfolio. Unfortunately, China does not report CPIS data. Constrained by this lack of data, we assume that international experience over the decade is still a relevant - even if only approximatebenchmark for China. For equities, country $i$ 's total securities portfolio consists of domestic stock market capitalization as reported in the World Bank's Global Financial Development Database plus all international equity assets of country $i$ minus country $i$ 's international equity liabilities. Similarly, for debt, the size of the domestic holdings is defined as outstanding domestic private and public debt securities as reported in the World Bank's

\footnotetext{
${ }^{10} \mathrm{We}$ have also used a log specification to confirm robustness. The regression results were broadly similar. The implications for China were also qualitatively similar in that they yielded a net outflow. However, this outflow was much smaller. Using coefficient estimates from the log regression amounted to applying a percentage to the share of foreign Chinese asset holdings in their total portfolio assets. This share is currently much smaller than in countries with comparably sized capital markets and nets to about 0 . Applying a percentage to these small numbers naturally yields much smaller projections. However, it fails to capture the discrete jump in levels that has typically followed past liberalizations.

${ }^{11}$ Sedik and Sun (2012) and He and others (2012), who estimate regression of capital flows on various countrylevel macroeconomic variables, address possible endogeneity by estimating GMM models.
} 
Global Financial Development Database. ${ }^{12}$ Although data on bilateral international equity and bond assets are available to 2011, the broader cross-country financial development indicators are only available to $2010 .^{13}$

The cost of investing in any country depend on the depth and size of financial markets, on capital controls, on information asymmetries, and return differentials and correlations. In line with Forbes (2010) but updating the data to 2010, the following variables are included to capture the cost of investing: ${ }^{14}$

- $\quad$ Financial market size: A larger financial market is likely to be a more liquid one and hence reduce the cost of investing. For regressions on equity assets, stock market capitalization in percent of GDP from the World Bank's Global Financial Development Database is used and for regressions on bond assets, outstanding domestic public and private debt securities in percent of GDP from the same database are used.

- Capital controls: Capital controls can raise the cost of investing cross-border both for residents and nonresidents. Schindler (2009) develops a detailed categorization of equity and bond inflow and outflow restrictions. Using the same methodology, his dataset is updated to 2011 .

- Information asymmetries: Existing trade or other nonfinancial ties and greater proximity are likely to reduce information asymmetries and reduce the cost of investment between any country pair. Such ties are proxied by bilateral trade (exports and imports) in percent of GDP using data from the IMF's DOTS database. The population-weighted geodesic distance between the largest cities of both partner countries is available from Mayer and Zignano (2011).

- $\quad$ Return differentials: A greater relative return in the host market makes portfolio investment in the host country more attractive. For regressions on equity portfolio assets, the annual average of monthly stock market returns for the stock market index with the broadest coverage in 59 countries in the sample is used based on Bloomberg

\footnotetext{
${ }^{12}$ Extreme outliers, in particular those with greater reported international debt or equity liabilities than the total size of the domestic market, are excluded. Those countries are all small offshore financial centers.

${ }^{13}$ The sample is further restricted to begin in 2005 by the requirement for FGLS estimation of a strictly balanced panel. If a strictly balance panel was constructed including earlier data, several large exposures in Asia (notably of Australia, New Zealand, and Korea), Europe (notably Russia) and Latin America (notably of Mexico) would be missing.

${ }^{14}$ For a review of results in the literature for each of these variables, see Forbes (2010). Forbes (2010) used data to 2006 .
} 
data. For regressions on bond portfolio assets, the annual average 5-year sovereign bond yield for 37 countries is used based on Bloomberg data.

- $\quad$ Return correlations: Risk diversification, e.g., as measured by a minimum variance portfiolio, is a key motivation for cross-border investment. Hence the bilateral correlation coefficient in monthly stock market returns or sovereign bond yields over the past three years is added as a control. Alternatively, high bilateral correlations may proxy fewer informational asymmetries.

- $\quad$ Governance: Better governance increases the transparency of investment and thus may reduce investment cost. Governance is proxied by the first standardized principle component of indicators of control of corruption, rule of law, and regulatory quality, all available from the World Bank's World Governance Indicators database.

As expected, the results confirm that international investors seek exposure to deeper financial markets and higher returns. Table 3 shows the baseline regression results for equities in columns I-II and for bonds in column IV-V. There is a concern that the bilateral holdings or the denominator in the dependent variable may be correlated with financial market size in the source and destination country, Columns III and VI show estimation results from an instrumental variables regression. For equity exposures, financial market size is instrumented with stock market value traded in percent of GDP (Column III). ${ }^{15}$ For bond exposures, financial market size is instrumented with the share of private debt in total domestic outstanding debt (Column VI). ${ }^{16}$ Table 4 tests the robustness of the results in column I and IV by removing each source and each destination country at a time and showing the range of coefficient estimates.

A few robust results stand out. First, for both asset classes, larger source country financial markets discourage domestic investors from investing abroad. The effect of larger destination market size is more complicated. Although in the baseline FGLS regressions larger destination markets attract foreign equity exposures, these results are not robust to our instrumental variables specification. In contrast, the counter-intuitive sign on destination bond market size in Columns III and IV corrects in our instrumental variables specification

\footnotetext{
${ }^{15}$ Its correlation with stock market capitalization - the measure of financial market size in the regressions for equities - is 72-76 percent (for destination and source country, respectively) whereas its correlation with the dependent variable is -4--7 percent (for destination and source country, respectively). First-stage regressions yield highly significant coefficient estimates of $0.4-0.41$. We interpret this as evidence that stock market trading volume is a legitimate instrument.

${ }^{16}$ The correlation of the share of private debt with total outstanding debt - our measure of financial market size in the regressions for bonds - is 17-32 percent (for source and destination country, respectively) whereas its correlation with the dependent variable is 3-8 percent (for source and destination country, respectively). Firststage regressions yield highly significant coefficient estimates of $0.31-0.52$ (for source and destination country, respectively). Again, we interpret this as evidence that the share of private debt is a legitimate instrument.
} 
or once Japan or the U.K. are removed from the sample: Japan — despite being the second largest bond market in the world - has only half the average share of global bond holdings; the U.K. - with a bond market one-eight the size of Japan's — on average accounts for four times the average share of bond holdings. If either of these two countries is removed from the sample, the sign reverses to the expected positive sign and is significant (Table 4). ${ }^{17}$ Second, higher returns in the destination country (and, for bonds, lower returns at home) also encourage greater exposures of domestic investors in foreign markets. Being significantly the opposite of the expected sign, the correlation in bond yields is clearly picking up effects other than diversification; this could reflect correlation being another proxy for information cost. Third, the other control variables have the expected signs: cross-border portfolio exposures are greater if home and host country have better governance and if there are greater other bilateral ties (greater trade and proximity). In general, bond exposures are more responsive than equity exposures to returns, source country financial market depth, destination country governance, and other bilateral ties. ${ }^{18}$

Capital controls both in the source and the destination country significantly reduce crossborder portfolio exposures. In general, equity exposures appear less sensitive to capital controls than bond exposures and less sensitive to destination country controls than source country controls. For equity exposures, the coefficients on capital controls on equity outflows from the source country and equity inflows into the destination country (Column II in Table 3 ) are somewhat stronger than a wider measure of controls that averages in- and outflows (Column I in Table 3).

What if investors, instead of separately deciding on bonds and equities portfolios, view equities and bonds as substitutes in their portfolio decision? Table 5 shows the results for the allocation of portfolio assets in total (bonds plus equities). Both the control variables and capital controls retain their significance and broadly similar magnitudes to those in the regression for bond exposures. However, returns in source and destination country are too poorly measured as simple averages to generate robust and significant coefficient estimates.

The results are broadly robust to including country dummies, a broader or narrower sample, or wider measures of capital controls. Columns I and VI of Table 6 show the baseline regressions of Table 3 as reference. Not surprisingly, adding country fixed effects (Columns II and VII) removes the significance of some of the country-level explanatory variables, including capital controls for both equities and bonds. During the sample period 2005-10,

\footnotetext{
${ }^{17}$ In addition, the effect of destination country controls on equity exposures are also not robust to removing the U.K. from the sample.

${ }^{18}$ A standard goodness of fit measure is not readily available for an FGLS regression. The Wald statistic testing joint significance of all coefficients is highly significant in all regressions. In addition, the correlation between the predicted and the actual values of the dependent variable is 17 percent for the regression in column I of Table 3 and 14 percent for the regression in column III of Table 3.
} 
capital controls were mostly unchanged. As a result, their effect is absorbed by country fixed effects. Stock market prices and sovereign bond yields are only available for a subsample of 59 and 37 countries, respectively. Columns III and VIII of Table 6 exclude assets returns and correlations and show results for the resulting larger sample. In this larger sample, the effect of restrictions on bond and equity flows shrink in magnitude but remain significant.

Replacing of the measure of capital controls in Schindler (2009) with that of capital account openness as in Chinn and Ito (2008) confirms that capital account openness increases bilateral exposures (except for source country controls in equity markets, Columns IV and IX). Finally, the two remaining large countries with heavily restricted capital accounts are China and India. Results excluding them — and Hong Kong SAR as gateway for investment in and from China - are shown in Columns V and X of Table 6. The coefficient estimates on capital controls remain significant and negative although they fall somewhat for equity exposures.

\section{IMPLICATIONS FOR CHINA AND CONCLUSIONS}

Using the coefficient estimates of the regressions above, one can speculate about the effects of Chinese capital account liberalization on the accumulation of foreign portfolio assets and liabilities. This speculation is necessarily partial-equilibrium. It does not take into account other changes in the macroeconomic environment that would occur as the capital account is opened: changes in interest rates domestically and abroad; structural changes in financial markets and institutions or governance; offsetting other investment flows; or offsetting changes in reserve accumulation policy.

The magnitude of the predicted stock adjustment in gross exposures and the resulting net flows is subject to substantial uncertainty, depending on the underlying regression specification. For example, applying the coefficient estimates on capital controls of Columns I through V of Table 3 and Columns III, V, VIII, and X of Table 6 to data for 2010 yields a wide range of estimates of counterfactual stock adjustments in China's international portfolio assets and liabilities had there been no capital controls. ${ }^{19}$ These estimates suggest

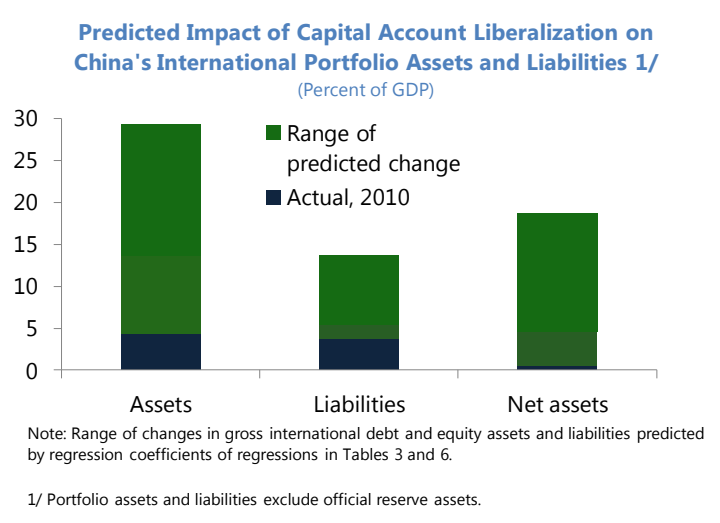
that capital account liberalization may be followed by a stock adjustment of Chinese assets abroad on the order of 15-25 percent of GDP and a smaller stock adjustment for foreign assets in China on the order of 2-10 percent of GDP.

\footnotetext{
${ }^{19}$ The calculation is done by multiplying the coefficient estimate with the assumed change in capital controls. This yields the predicted change in each source country's holdings in percent of its total market size. Multiplying by source country market size and adding across source countries yields the total change in exposures in the counterfactual scenario compared with the actual 2010 data.
} 
This would imply a net accumulation of Chinese net international assets of 11-18 percent of GDP (Table 7). While the magnitudes differ, the direction is in line with that estimated by He and others (2012) and Sendik and Sun (2012).

One concern with these estimates is that the size of the Chinese financial markets may be overstated by aggregate market capitalization and outstanding debt. Nontradable shares account for about one quarter of equity market capitalization. In the bond market, bond market debt may have substituted for bank lending since almost half of the outstanding bond market debt is held by banks. Once equity and bond market size is adjusted for these two factors, the predicted net accumulation of portfolio assets would narrow to 4-8 percent of GDP.

A similar thought experiment can be conducted for India, the other large economy with extensive capital account restrictions. By all of the three widely used capital account openness measures (see Section I), India's capital account restrictions are the same as China's. However, the regression equations suggest that a capital account opening may lead to more balanced gross flows, with possibly some net Predicted Impact of Capital Account Liberalization on India's International Portfolio Assets and Liabilities 1/

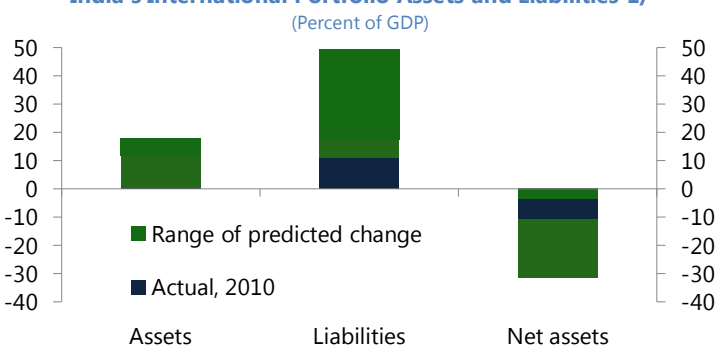
inflows especially into the bond market.

The discrepancy in the effect on Chinese and Indian assets abroad reflects the different size of existing total portfolio assets that could potentially be diversified abroad by domestic investors. China's stock market capitalization was the second largest in the sample in 2010 and its outstanding debt the sixth largest. Indian bond and stock market sizes were about one quarter those of their Chinese equivalent. Hence, if Indian investors diversify the same fraction of their holdings abroad as Chinese investors, their reallocation accounts for much smaller nominal amounts (although of similar orders of magnitude in percent of GDP because Indian GDP was also about one quarter that of China's in 2010). The discrepancy in the effect on Indian and Chinese liabilities to foreigners reflects the smaller size of the Indian economy: since Indian GDP is about one quarter that of China, similar flows triggered by capital account opening would account for about four times the share of the Indian economy compared with that of the Chinese economy. 
Capital account liberalization is likely to proceed gradually. Similarly, the net outflows the model predicts for China could well be spread out over several years and, over this period, would partially offset other balance of payments inflows over the medium-term. The July 2013 World Economic Outlook Update projects a widening current account surplus to 4.1 percent of GDP by 2018 and continued net FDI inflows. As a result, reserve accumulation is expected to continue on the order of USD 580 billion per year on average over the period 2013-18. Were

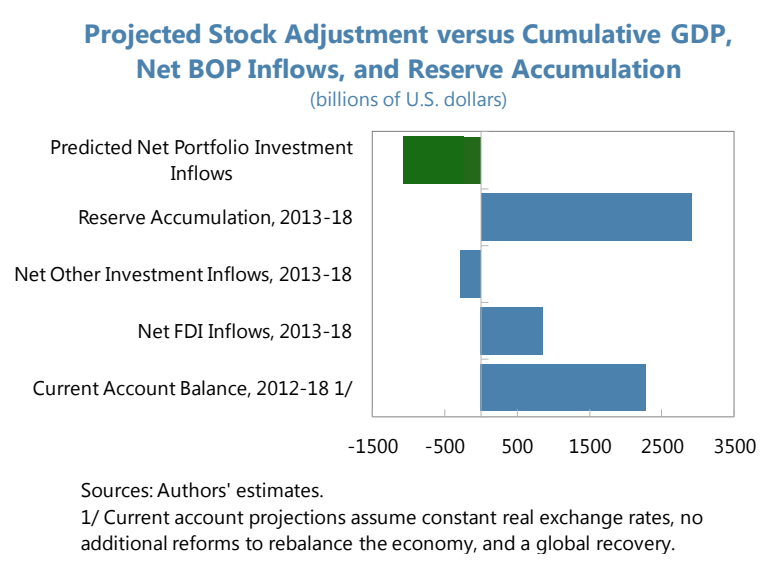
our predicted stock adjustment in net portfolio assets phased over a similar 5-year horizon, reserve accumulation could be reduced by up to one-third.

An accumulation of 9-25 percent of GDP in international portfolio assets by Chinese residents could have significant repercussions for global asset prices. If allocated along MSCI portfolio shares, it would account for up to 3 percent of global financial markets or up to a quarter of financial markets in emerging market economies. If the Chinese authorities were to offset all or parts of these Equivalents of 9.4-24.5 percent of Chinese GDP, 2010

\begin{tabular}{|l|l|l|l|l|}
\hline & $\begin{array}{l}\text { Equity impact } \\
\text { in \% of stock } \\
\text { market } \\
\text { capitalization }\end{array}$ & $\begin{array}{l}\text { Portfolio debt } \\
\text { impact in \% of } \\
\text { outstanding } \\
\text { portfolio debt }\end{array}$ & $\begin{array}{l}\text { Total impact in \% } \\
\text { of stock and } \\
\text { debt market size }\end{array}$ & $\begin{array}{l}\text { Total impact } \\
\text { (trillions of } \\
\text { U.S. dollars) }\end{array}$ \\
\hline MSCl global & $0-1$ & $0-1$ & $0-1$ & $0.6-1.5$ \\
\hline US & $0-2$ & $1-3$ & $1-2$ & $0.4-1$ \\
\hline UK & $0-1$ & $1-3$ & $1-2$ & $0.1-0.2$ \\
\hline Japan & $0-1$ & $0-1$ & $0-1$ & $0.1-0.2$ \\
\hline Canada & $0-1$ & $1-3$ & $1-2$ & $0-0.1$ \\
\hline France & $0-1$ & $0-1$ & $0-1$ & $0-0.1$ \\
\hline EM excl. China & $1-5$ & $7-23$ & $4-10$ & $0.6-1.5$ \\
\hline
\end{tabular}
Sources: GFSR April 2012 for 2010 market sizes; MSCI factsheet 2013 for shares, rescaled to exclude an unspecified "Other". outflows by slowing reserve accumulation or reserve drawdown, yields on reserve assets could come under pressure.

Benelli (2011) estimates that a $\$ 500$ billion (some 7 percent of China's 2011 GDP) shift out of U.S. public debt into emerging market government debt could increase U.S. bond yields by 60 bps and decrease emerging market bond yields by 240 bps. Benelli's (2011) premise is that the Chinese authorities choose to reallocate their reserve holdings away from U.S. debt towards emerging market debt. A similar reallocation would be achieved if capital account liberalization in China led to gross portfolio outflows that were offset by a drawdown of official reserves. Here, the potential order of magnitude for such a reallocation is significantly larger than Benelli's (2011) thought experiment.

By opening up alternative investment opportunities for savings, capital account liberalization in China could also have important repercussions for Chinese financial markets. Interest rate regulation continues to depress returns on bank deposits, which have offered negative real returns since 2003. Alternative instruments for household savings are the stock market, "wealth management products", and the property market. The Chinese stock market remains a highly speculative investment vehicle for household savings (Mei and others, 2009). With 
less volatility, residential investment has yielded significantly higher returns than deposits: year-on-year returns since 2005 have averaged 101/2 percent countrywide and year-on-year price declines have thus far never lasted longer than four months before rebounding. Finally, wealth management products have generated yields substantially above regulated benchmark deposit rates — on average 2 percentage points for one-year deposits in 2012 (Barclays, 2013). As a result, by some estimates (Barclays, 2013), these products have grown sevenfold since end-2009 to RMB 7.1 trillion (15 percent of GDP) by end-2012. If households savings gained access to global financial markets, liquidity in these three domestic financial markets could shrink.

In sum, our econometric results as well as the stylized facts from past capital account liberalizations suggest three conclusions:

- $\quad$ Capital account opening in China will likely be followed by substantial gross portfolio flows as global and domestic portfolio holdings adjust.

- $\quad$ During the adjustment period there may be net outflows from both equity and bond markets as domestic investors seek to diversify large domestic savings. This is in contrast to what would be expected if, say, India opened its capital account.

- $\quad$ Such net outflows of portfolio investment could offset pressures for reserve accumulation from net FDI or other investment inflows or current account surpluses for several years to come. 


\section{Box 1. Country Examples of Capital Account Liberalization}

There are several helpful examples of liberalizations since the 1970s that "succeeded" or contributed to subsequent crises (Rodlauer and N'Diaye (eds), 2013).

Best practice. The following factors remain relevant for smooth capital account opening.

- Implemented in an environment of macroeconomic balance, fiscal discipline and tight financial system supervision. A current account surplus helps.

- Following the textbook sequencing: short-term flows liberalized before long-term flows, inflows before outflows, and FDI before debt flows.

- Interaction with financial sector and exchange rate reform. To succeed in establishing a market based exchange rate, exchange rate flexibility needs the two-way capital flows of a liberalized capital account; financial market liberalization helps develop a yield curve for a functioning exchange rate market and avoid the buildup of domestic foreign currency mismatches.

- Even in the best of circumstances, the effect of capital account liberalization remains difficult to anticipate. Many relationships are highly nonlinear (Prasad and Rajan, 2008). For example, widely expected large and persistent net capital outflows in Israel and Sweden never materialized.

\section{Five country examples.}

- Poland: Pressures to finance the budget deficit forced the authorities to liberalize short-term debt flows before long-term FDI flows. However, to offset financial stability risks, intrusive bank supervision constrained flows entering through the liberalized capital account into the banking system.

- Korea: Korea's capital account liberalization was sequenced in an unconventional manner, liberalizing short-term bank flows before corporate flows, portfolio flow liberalization before exchange rate liberalization and FDI liberalization. This sequencing supported large external borrowing and a buildup of foreign currency mismatches in balance sheets.

- Turkey: Capital account liberalization during the 1980s (completed by 1989) under fiscal dominance and an underdeveloped banking systems was followed by destabilizing capital inflows and two crises, in 1994 and 2001.

- Israel: Israel implemented two capital account liberalizations: a "big bang" in 1977 that was reversed within $1 \frac{1}{2}$ years and a gradual liberalization in 1987-2005. The "big bang" liberalization was a 50 percent devaluation and full exchange rate and capital account liberalization in the context of underdeveloped capital markets, a lack of hedging markets, and severe macroeconomic imbalances. It was followed by large inflows that subsequently reversed. Restrictions were re-imposed in 1979. The second liberalization was accompanied by macroeconomic stabilization, followed the conventional sequencing and a careful phasing by sector (beginning with foreign residents, then new immigrants, asset managers, corporates, and finally households). Approval requirements were converted into reporting requirements resulting in an important database for monitoring vulnerabilities.

- Sweden: Sweden liberalized bond markets first, followed by financial sector liberalization in 1985, and partial capital account deregulation beginning in 1989. Pre-1985, the financial sector was centrally planned. When bank lending was liberalized, a credit boom to satisfy pent-up demand followed, coinciding with large fiscal deficits and rising inflation. A tax change in 1991 raised the real interest rate from $-1 \%$ to $4 \%$ overnight and ended the credit boom. The fixed exchange rate could not be defended absent capital controls and was allowed to float. 


\section{Box 2. U.K. Removal of Exchange Controls in 1979-80}

Previous regime. While the amount of FDI flows was unrestricted, their domestic financing was restricted. Portfolio investments were confined to the offshore market.

- Sterling-financed outward FDI (at official exchange rates) had to improve the balance of payments.

- Foreign borrowing-financed outward FDI was freely allowed and subsequent profits from such FDI could be freely used to repay the foreign borrowing.

- Foreign currency transactions related to outward FDI not financed by foreign borrowing, to portfolio flows, and to other investment had to be channeled through the "investment currency market". All purchases of foreign exchange in the investment currency market were financed only by the sale of existing securities and by foreign borrowing. This created a parallel exchange rate in the investment currency market that persistently demanded a 30-50 percent premium over the official exchange rate. To prevent leakages, at least two thirds of after-tax profits from outward FDI had to be repatriated and, until end-1977, at least 25 percent of the proceeds of the sale of foreign portfolio securities had to be exchanged at the official exchange rate ("surrender penalty").

- Foreign currency deposits of residents were restricted to working balances and domestic currency lending by resident banks to nonresidents was restricted to trade-related purposes.

Reforms. From June 1979, interest payments on foreign borrowing and repayment of foreign borrowing with maturities above one year could be financed at the official exchange rate and all restrictions related to financing FDI and on European Economic Community securities were lifted. All remaining restrictions on portfolio investments were lifted in October 1979. Separately, in June 1980, additional reserve requirements on domestic banks for credit growth in excess of 1 percent per month were lifted, thus reducing incentives for banks to move trade credit off balance sheet into the commercial bill market.

Impact. Artis and Taylor (1989) and Bank of England (1981) estimate the impact of the abolition of the controls. These estimates do not take into account that, simultaneously, the new Thatcher government launched a series of macroeconomic stabilization and labor market reforms and the North Sea oil came on stream. The pound appreciated strongly and domestic interest rates rose.

- Change in financing of FDI. Levels of FDI were unaffected but about GBP 638 million ( 0.27 percent of GDP) of FDI-related foreign borrowing were refinanced. The share of repatriated foreign earnings initially dropped from 47 percent to 37 percent but subsequently increased again.

- Increased portfolio outflows. Portfolio investment outflows increased from negligible amounts to GBP 45 billion (20 percent of GDP) although this was partly offset by increased portfolio inflows, such that the overall impact was to increased net portfolio outflows by some GBP 30 billion (13 percent of GDP). The abolition of the controls triggered a substantial reallocation of investment portfolios of pension, investment, and unit trust funds. The foreign share of net investment flows increased from 7 to 20 percent for pension funds, from 4 to 17 percent for insurance companies, and to 100 percent for unit trust funds.

- Foreign currency deposits of residents. Residents' foreign currency deposits in U.K. banks doubled while their foreign currency borrowing increased by one third. Residents' foreign currency deposits and borrowing from foreign banks both increased by about half as much again. Sterling lending by U.K. banks to nonresidents - mostly foreign banks - increased from about GBP 6 million per month in September 1979 to GBP 300 million (0.13 percent of GDP) in June 1981. Some of this was offset by rising Sterling deposits of nonresident banks with U.K. banks.

- Onshore/offshore interest rate differential disappeared. The onshore/offshore interest rate differential dropped from about 4 percent in late 1978 to close to zero by end-1979 and remained around zero thereafter. The deviation from covered interest parity also virtually closed. 


\section{Box 3. Japan. Removal of Exchange Controls in 1979-80}

Previous regime. Japan oscillated between imposing capital inflow and outflow controls depending on exchange rate pressures. OECD (1984) identify several waves of capital controls: (i) 1970-72, tightening of already strict capital inflow controls and easing of outflow controls in response to current account surpluses; (ii) 1973-74, easing of restrictions on inflows and tightening of restrictions on outflows in response to current account deficits and capital outflows; (iii) 1975-77, easing of all restrictions as exchange pressures eased; and (iv) 1977-78, tightening of inflow controls to contain short-term capital inflows. By 1978, nonresident yen deposits (a key channel for short-term capital inflows) were subjected to a 100 percent reserve requirement and foreign debt to a reserve requirement of 0.25 percent. Banks were subject to a daily conversion limit of foreign currency into yen. Nonresident purchases of yendenominated securities were strictly controlled and nonresident purchases of government bonds prohibited. Residents were prohibited from issuing foreign currency bonds or yen-denominated foreign bonds and nonresident issuance of yen-denominated bonds was restricted. Foreign currency borrowing by residents was tightly controlled. Offshore interest rates (euroyen rates) were about 5 percent below onshore money market rates (Fukao, 1995). The domestic financial system remained subject to regulation of deposit rates and a strict separation of banks between those engaged in short-term lending, those engaged in long-term lending, those engaged in foreign exchange deposit-taking, trust funds, and securities firms.

Reforms. All remaining capital account restrictions on both outflows and inflows were removed in 1979/1980. Domestic interest rates remained heavily regulated and the main push for financial sector liberalization occurred only around 1985.

- Capital account liberalization 1979-80. In January and February 1979, reserve requirements on nonresident yen deposits and restrictions on nonresident purchases of yen-denominated securities were eliminated. In May 1979, the government bond (Gensaki) market was opened to nonresidents. In November 1979, the quota for foreign currency conversion by banks was increased. Restrictions on medium and long-term foreign currency borrowing by corporates were successively relaxed between February 1979 and March 1980. In March 1980, limits on interbank transfers to domestic banks were raised, interest rates on foreign deposit in domestic banks were liberalized, and Japanese banks were allowed to issue yen-denominated foreign bonds. In 1981 and 1983, foreign asset holdings were permitted for pension funds and postal life insurance funds up to ceilings of 10 percent of assets.

- Financial liberalization 1979-92. A market with liberalized interest rates was introduced for commercial deposits in May 1979, for money market certificates in March 1985, for yendenominated bankers' acceptances in September 1985, and for commercial paper in November 1987. Interest rates for large time deposits were liberalized in October 1985, for all times deposits in June 1993, and for all sight deposits in October 1994 (Aramaki, 2006). The Tokyo offshore market, established in December 1986, allowed resident banks to take deposits and lend to nonresidents without the restrictions applying to domestic banking. Competition between banks, trust funds, and securities firms was allowed in June 1992.

\section{Impact.}

- Net capital outflows. In the five years following capital account liberalization, net foreign assets increased by some 10 percent of GDP. Especially the permission for institutional investors to acquire foreign assets generated strong capital outflow pressures (Fukua, 1995). However, far larger flows followed financial system liberalization: Between 1985 and 1990, foreign assets and liabilities increased by some 30 percent of GDP each, whereas net foreign assets remained broadly around 10 percent of GDP.

- Onshore/offshore interest rate differential disappeared. The differential between the London euroyen market rate and the domestic money market rate dropped from about 5 percent in early 1979 to close to zero by end-1979 and remained around zero thereafter (Fukao, 1995, Maloney, 1992). 


\section{TABLES}

Table 1. Capital Account Restrictions in China

FDI

Inflow restrictions

Outflow restrictions

\section{Portfolio investment}

Average equity restrictions

Equity inflow restrictions

Purchase locally by nonresidents (equity)

Sale or issue abroad by residents (equity)

Equity outflow restrictions

Sale or issue locally by nonresidents (equity)

Purchase abroad by residents (equity)

Average bond restrictions

Bond inflow restrictions

Purchase locally by nonresidents (bond)

Sale or issue abroad by residents (bond)

Bond outflow restrictions

Sale or issue locally by nonresidents (bond)

Purchase abroad by residents (bond)

Average money market restrictions

Money market inflow restrictions

Purchase locally by nonresidents (money market)

Sale or issue abroad by residents (money market)

Money market outflow restrictions

Sale or issue locally by nonresidents (money market)

Purchase abroad by residents (money market)
Approval by Ministry of Commerce, local branches of the PBoC (for R-FDI), or local commerce agencies

In start-up phase, transfers require SAFE approval.

QFIIs may hold minority stakes in A shares (denominated in RMB), up to an aggregate ceiling of USD 80 billion.

Currency conversion and repatriation of principal for all QFIIs other than open-end China funds require SAFE approval.

CSRC approval

Sale allowed for QFII but subject to initial lock-up period of 3-12 month depending on type of QFII; Issue unrestricted in principle (but unprecedented)

Approved QDII subject to institution-specific ceilings

Approved QFII subject to aggregate and institution-specific ceilings.

NDRC and State Council approval

Allowed for QFII subject to initial lock up period of 3-12 months depending on type of QFII vehicle; MOF, PBC, and NDRC approval for issuance (unprecedented)

Approved QDII subject to institution-specific ceilings

Approved QFII subject to aggregate and institution-specific ceilings.

Only for maturities $<1$ year and only with SAFE approval.

Sale allowed for QFII subject to initial lock up period of 3-12 months depending on type of QFII vehicle; Issuance prohibited.

Approved QDII subject to institution-specific ceilings 
Table 1. Capital Account Restrictions in China (concluded)

\section{Other investment}

Average collective investment restrictions

Collective investment inflow restrictions

Purchase locally by nonresidents (collective investment)

Sale or issue abroad by residents (collective investment)

Collective investment outflow restrictions

Sale or issue locally by nonresidents (collective

investment)

Purchase abroad by residents (collective investment)

Average financial credit restrictions

Financial credit inflow restrictions

Financial credit outflow restrictions

A

Ar

$\cdots$

QFIIs may hold minority stakes in A shares (denominated in RMB), up to an aggregate ceiling of USD 80 billion. Currency conversion and repatriation of principal for all QFIIs other than open-end China funds require SAFE approval.

SAFE approval.

$\cdots$

Prohibited

Approved QDII subject to institution-specific ceilings

Loans from nonresidents to preapproved domestic banks and corporates are allowed as long as they have maturities below 1 year and are within the overall limits established by SAFE. Longer-term loans require NDRC approval. SAFE approval required for resident MNC to provide loans to nonresident MNC.

Resident institutions may open foreign currency accounts domestically but may hold balances in them only for operating needs. With SAFE approval, they may also open foreign currency accounts abroad if they can prove foreign payment requirements and fulfill origin of export requirements. Resident individuals may open foreign currency savings accounts domestically, but documentation is required for account balances in excess of USD 50,000 . Residents are not allowed to hold RMB accounts abroad. Nonresident investors may open foreign currency accounts subject to SAFE approval. Also subject to SAFE approval, nonresidents may maintain onshore RMB accounts for purposes of offshore RMB settlement or trade settlement purposes. Nonresident individuals may open foreign currency accounts.

Real estate purchases by residents abroad are allowed but domestic real estate purchases by nonresidents are restricted to self-use and the conversion of liquidation proceeds requires SAFE approval. Transfer of emigrants' assets requires approval and is only allowed in steps. A pilot project "Wenzhou project" allows a capital outflow of up to RMB 3 million per person per year.

Source: AREAR (2011). 
SCHINDLER financial account restrictions (2010)

Overall restrictions index $1 /$

Overall inflow restrictions index

Overall outflow restrictions index

Overall non-FDI financial account restrictions index

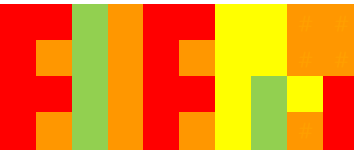

\section{Portfolio investment}

Average equity restrictions

Equity inflow restrictions

Purchase locally by nonresidents (equity)

Sale or issue abroad by residents (equity)

Equity outflow restrictions

Sale or issue locally by nonresidents (equity)

Purchase abroad by residents (equity)

Average bond restrictions

Bond inflow restrictions

Purchase locally by nonresidents (bond)

Sale or issue abroad by residents (bond)

Bond outflow restrictions

Sale or issue locally by nonresidents (bond)

Purchase abroad by residents (bond)

Average money market restrictions

Money market inflow restrictions

Purchase locally by nonresidents (money market)

Sale or issue abroad by residents (money market)

Money market outflow restrictions

Sale or issue locally by nonresidents (money market)

Purchase abroad by residents (money market)

Source: Schindler (2009), extended to 2010

Note: Red denotes either a restriction beyond reporting requirements. Green denotes no restrictions. Yellow in an aggregate position denotes one out of four categories are restricted; orange in an aggregate position denotes two out of four categories are restricted; red in an aggregate position denotes three or four out of four categories are restricted.

FDI

Abroad

In reporting economy

Other investment

Average collective investment restrictions

Collective investment inflow restrictions

Purchase locally by nonresidents (collective investment)

Sale or issue abroad by residents (collective investment) Collective investment outflow restrictions

Sale or issue locally by nonresidents (collective investment)

Purchase abroad by residents (collective investment)

Average financial credit restrictions

Financial credit inflow restrictions

Financial credit outflow restrictions

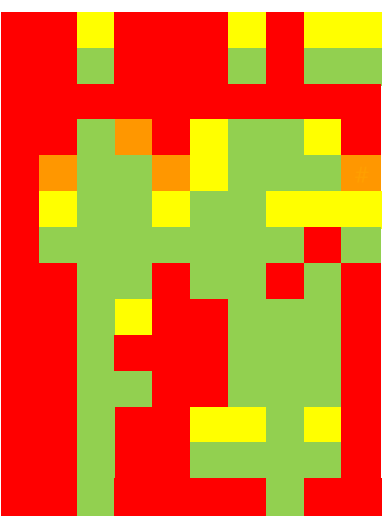


Table 3. FGLS regression: Share of bilateral portfolio assets in total portfolio, 2005-2010

\begin{tabular}{|c|c|c|c|c|c|c|}
\hline & $(1)$ & (2) & (3) & $(4)$ & (5) & (6) \\
\hline VARIABLES & Stocks & Stocks & IV $1 /$ & Bonds & Bonds & $\begin{array}{l}\text { IV (private } \\
\text { share) } 2 /\end{array}$ \\
\hline \multirow[t]{2}{*}{ Share of destination in global portfolio } & $0.115^{\star \star \star}$ & $0.116^{\star \star *}$ & $0.120^{\star \star \star}$ & $0.141^{\star * *}$ & $0.131^{\star * *}$ & $0.166^{\star \star \star}$ \\
\hline & (0) & (0) & (0) & (0) & $(0)$ & (0) \\
\hline Stock market capitalization or outstanding domestic bonds (\% of GDP) in source & $-0.00204^{* *}$ & $-0.00200^{\star \star *}$ & $-0.00252^{* * *}$ & $-0.00723^{* * *}$ & $-0.00571^{* * *}$ & $\frac{-0.00471^{* * *}}{(0)}$ \\
\hline \multirow{2}{*}{ Stock market capitalization or outstanding domestic bonds (\% of GDP) in destination } & $0.000376^{* * *}$ & $0.000287^{* *}$ & $-0.00165^{\star \star \star}$ & $\begin{array}{c}(0) \\
-0.00286^{\star * *}\end{array}$ & $\begin{array}{c}(0) \\
-0.00126^{* *}\end{array}$ & $\begin{array}{c}\text { (U) } \\
0.0209^{\star \star \star}\end{array}$ \\
\hline & $(0.00141)$ & $(0.0170)$ & $(0)$ & $(1.48 \mathrm{e}-06)$ & $(0.0147)$ & $(0)$ \\
\hline \multirow[t]{2}{*}{ Inflow or outflow restrictions in source } & $-0.107^{\star \star \star}$ & & $-0.102^{\star \star \star}$ & $-0.685^{\star \star \star}$ & & $-0.577^{\star \star \star}$ \\
\hline & $(1.18 \mathrm{e}-05)$ & & $(5.91 \mathrm{e}-06)$ & (0) & & (0) \\
\hline \multirow[t]{2}{*}{ Outflow restrictions in source } & & $-0.154^{\star \star \star}$ & & & $-0.362^{* \star *}$ & \\
\hline & & (0) & & & (0) & \\
\hline \multirow{2}{*}{ Inflow or outflow restrictions in destination } & $-0.0448^{\star *}$ & & $-0.106^{\star \star \star}$ & $-0.711^{\star * *}$ & & $-0.374^{\star \star *}$ \\
\hline & $(0.0249)$ & & $(6.76 \mathrm{e}-08)$ & (0) & & $(9.84 \mathrm{e}-10)$ \\
\hline \multirow[t]{2}{*}{ Inflow restrictions in destination } & & $-0.0495^{\star \star \star}$ & & & $-0.127^{\star \star}$ & \\
\hline & & $(0.00343)$ & & & $(0.0401)$ & \\
\hline \multirow[t]{2}{*}{ Governance in source } & $0.218^{* * *}$ & $0.208^{* * *}$ & $0.205^{\star \star \star}$ & $0.136^{* * *}$ & $0.163^{* * *}$ & $0.280^{\star \star *}$ \\
\hline & (0) & (0) & (0) & (0) & (0) & (0) \\
\hline \multirow{2}{*}{ Governance in destination } & $0.111^{\star \star \star}$ & $0.113^{\star \star \star}$ & $0.119^{* \star *}$ & $0.157^{* * *}$ & $0.203^{\star \star \star}$ & $0.162^{* \star *}$ \\
\hline & $(0)$ & (0) & (0) & (0) & (0) & (0) \\
\hline \multirow[t]{2}{*}{ Bilateral trade (\% of destination GDP) } & $0.0394^{\star \star \star}$ & $0.0398^{\star \star \star}$ & $0.0352^{\star * \star}$ & $0.0583^{* \star *}$ & $0.0644^{* \star *}$ & $0.0473^{\star \star \star}$ \\
\hline & $(0)$ & $(0)$ & $(0)$ & $(0)$ & (0) & $(5.15 \mathrm{e}-08)$ \\
\hline \multirow[t]{2}{*}{ Log distance } & $-0.353^{\star \star \star}$ & $-0.355^{\star \star *}$ & $-0.392^{\star \star \star}$ & $-0.826^{\star \star \star}$ & $-0.774^{\star \star \star}$ & $-1.097^{\star \star \star}$ \\
\hline & (0) & (0) & (0) & (0) & (0) & (0) \\
\hline \multirow[t]{2}{*}{ Stock market return or bond yield in source } & 0.0104 & 0.00716 & $0.0246^{\star * \star}$ & $-0.145^{\star \star *}$ & $-0.120^{\star \star \star}$ & $-0.0809^{* * *}$ \\
\hline & $(0.157)$ & $(0.330)$ & $(0.000714)$ & (0) & (0) & (0) \\
\hline \multirow[t]{2}{*}{ Stock market return or bond yield in destination } & $0.0164^{* * *}$ & $0.0195^{* * *}$ & $0.0125^{*}$ & $0.0496^{* * *}$ & $0.0527^{* * *}$ & $0.193^{* * *}$ \\
\hline & $(0.00849)$ & $(0.00165)$ & $(0.0560)$ & (0) & (0) & (0) \\
\hline \multirow[t]{2}{*}{ Correlation in stock market returns or sovereign bond yields } & $0.359^{* * *}$ & $0.385^{* * *}$ & $0.339^{* * *}$ & $0.114^{\star * *}$ & $0.0905^{\star * *}$ & $0.217^{* \star *}$ \\
\hline & (0) & (0) & (0) & $(1.76 \mathrm{e}-08)$ & $(9.80 \mathrm{e}-06)$ & (0) \\
\hline \multirow[t]{2}{*}{ Constant } & $2.658^{* * *}$ & $2.711^{* * *}$ & $3.175^{\star * *}$ & $8.613^{* * *}$ & $7.338^{\star \star *}$ & $7.631^{\star \star \star}$ \\
\hline & (0) & (0) & (0) & (0) & (0) & (0) \\
\hline Observations & 8,382 & 8,382 & 8,382 & 4,278 & 4,278 & 3,636 \\
\hline Number of node12code & 1,397 & 1,397 & 1,397 & 713 & 713 & 713 \\
\hline Wald statistic & 5549 & 5970 & 6724 & 3229 & 2142 & 41942 \\
\hline \multicolumn{7}{|l|}{ pval in parentheses } \\
\hline \multicolumn{7}{|l|}{${ }^{\star \star *} p<0.01,{ }^{* *} p<0.05,{ }^{*} p<0.1$} \\
\hline \multicolumn{7}{|l|}{ Note: Regression includes time fixed effects. } \\
\hline 1 / Stock market capitalization is instrumented wit & of GDP. & & & & & \\
\hline
\end{tabular}


Table 5. Panel regression: Share of bilateral portfolio assets in total portfolio, 2005-2010

\begin{tabular}{|c|c|c|c|c|}
\hline & $(1)$ & $(2)$ & (3) & (4) \\
\hline \multicolumn{5}{|l|}{ VARIABLES } \\
\hline \multirow[t]{2}{*}{ Destination's share of global portfolio } & $0.149^{\star * *}$ & $0.146^{\star \star *}$ & $0.147^{\star \star *}$ & $0.131^{\star \star *}$ \\
\hline & $(0)$ & $(0)$ & $(0)$ & $(0)$ \\
\hline \multirow[t]{2}{*}{ Equity market capitalization and outstanding bonds (\% of GDP) in source } & $-0.00244^{\star * *}$ & $-0.00255^{\star * *}$ & $-0.00262^{\star \star *}$ & $-0.00224^{* * *}$ \\
\hline & $(0)$ & $(0)$ & $(0)$ & $(0)$ \\
\hline \multirow[t]{2}{*}{ Equity market capitalization and outstanding bonds ( $\%$ of GDP) in destination } & $-0.00148^{* * *}$ & $-0.00143^{\star \star *}$ & $-0.00148^{\star * *}$ & $-0.00134^{* * *}$ \\
\hline & $(0)$ & $(0)$ & $(0)$ & $(0)$ \\
\hline \multirow[t]{2}{*}{ Portfolio flow restriction in source } & $-0.797^{* * *}$ & & $-0.778^{* \star *}$ & $-0.585^{\star \star \star}$ \\
\hline & $(0)$ & & (0) & (0) \\
\hline \multirow[t]{2}{*}{ Portfolio outflow restriction in source } & & $-0.572^{\star \star \star}$ & & \\
\hline & & (0) & & \\
\hline \multirow[t]{2}{*}{ Portfolio flow restriction in destination } & $-0.833^{* * *}$ & & $-0.858^{\star * *}$ & $-0.822^{\star \star \star}$ \\
\hline & $(0)$ & & $(0)$ & $(0)$ \\
\hline \multirow[t]{2}{*}{ Portfolio inflow restriction in destination } & & $-0.399^{\star \star *}$ & & \\
\hline & & $(0)$ & & \\
\hline \multirow[t]{2}{*}{ Governance in source } & $0.356^{\star \star \star}$ & $0.317^{\star \star \star}$ & $0.357^{\star \star \star}$ & $0.303^{\star \star \star}$ \\
\hline & $(0)$ & $(0)$ & $(0)$ & $(0)$ \\
\hline \multirow{2}{*}{ Governance in destination } & $0.0525^{* * *}$ & $0.153^{\star \star *}$ & $0.0662^{\star \star \star}$ & $0.0467^{\star \star \star}$ \\
\hline & $(0.000160)$ & $(0)$ & $(4.51 \mathrm{e}-06)$ & $(3.16 e-08)$ \\
\hline \multirow[t]{2}{*}{ Bilateral trade (\% of destination GDP) } & $0.0370^{\star \star \star}$ & $0.0313^{\star * \star}$ & $0.0392^{\star \star *}$ & $0.0370^{\star * \star}$ \\
\hline & $(4.85 e-10)$ & $(7.80 e-09)$ & $(0)$ & $(0)$ \\
\hline \multirow[t]{2}{*}{ Log distance } & $-0.511^{\star \star \star}$ & $-0.500^{\star \star \star}$ & $-0.543^{\star * *}$ & $-0.403^{\star \star \star}$ \\
\hline & $(0)$ & $(0)$ & $(0)$ & $(0)$ \\
\hline \multirow[t]{2}{*}{ Average stock market return and bond yield in source } & $-0.140^{* * *}$ & $-0.185^{\star \star \star}$ & & \\
\hline & $(0)$ & $(0)$ & & \\
\hline \multirow[t]{2}{*}{ Average stock market return and bond yield in destination } & -0.00954 & $0.0300^{\star \star *}$ & & \\
\hline & $(0.331)$ & $(0.00162)$ & & \\
\hline \multirow[t]{2}{*}{ Average of stock market return and bond yield correlation } & $0.0923^{\star \star \star}$ & $0.0983^{\star \star \star}$ & & \\
\hline & $(0.000607)$ & $(0.000254)$ & & \\
\hline \multirow[t]{2}{*}{ Bond yield in source } & & & $-0.0787^{\star \star \star}$ & \\
\hline & & & $(0)$ & \\
\hline \multirow[t]{2}{*}{ Bond yield in destination } & & & 0.00207 & \\
\hline & & & $(0.678)$ & \\
\hline \multirow[t]{2}{*}{ Correlation in sovereign bond yields } & & & 0.0205 & \\
\hline & & & $(0.133)$ & \\
\hline \multirow[t]{2}{*}{ Stock market return in source } & & & & 0.0114 \\
\hline & & & & $(0.539)$ \\
\hline \multirow[t]{2}{*}{ Stock market return in destination } & & & & $-0.0546^{\star \star \star}$ \\
\hline & & & & $(7.27 e-05)$ \\
\hline \multirow[t]{2}{*}{ Correlation in stock market returns } & & & & $0.665^{\star \star \star}$ \\
\hline & & & & $\quad(0)$ \\
\hline \multirow[t]{2}{*}{ Constant } & $5.241^{\star \star \star}$ & $4.852^{\star \star \star}$ & $5.544^{\star \star \star}$ & $3.800^{\star \star \star}$ \\
\hline & $(0)$ & $(0)$ & $(0)$ & $(0)$ \\
\hline Observations & 4,002 & 4,002 & 4,002 & 4,002 \\
\hline Number of node12code & 667 & 667 & 667 & 667 \\
\hline Wald statistic & 4188 & 3863 & 4468 & 5069 \\
\hline pval in parentheses & & & & \\
\hline${ }^{\star * *} p<0.01,{ }^{* *} p<0.05,{ }^{*} p<0.1$ & & & & \\
\hline Note: Regression includes time fixed effects. & & & & \\
\hline
\end{tabular}


Table 6. FGLS regression: Share of bilateral portfolio assets in total portfolio, 2005-2010

\begin{tabular}{|c|c|c|c|c|c|c|c|c|c|c|}
\hline \multirow[b]{2}{*}{ VARIABLES } & \multicolumn{5}{|c|}{ Stocks } & \multicolumn{5}{|c|}{ Bonds } \\
\hline & Baseline I & country FE II & II larger sample III & Chinn-Ito IV & excl HKG CHN IND V & Baseline VI & country FE VI & VIII larger sample VIII & Chinn-Ito IX & excl HKG CHN IND X \\
\hline Share of destination in global portfolio & 0.115 & 0.0265 & 0.114 & 0.126 & 0.131 & 0.141 & 0.0556 & 0.136 & 0.150 & 0.130 \\
\hline & $(0)^{* \star *}$ & $(5.16 \mathrm{e}-05)^{\star \star \star}$ & $(0)^{\star \star \star \star}$ & $(0)^{* * *}$ & $(0)^{* \star \star}$ & $(0)^{* * *}$ & $(0.0135)^{\star \star}$ & $(0)^{* \star \star}$ & $(0)^{* \star *}$ & $(0)^{* * *}$ \\
\hline Stock market capitalization or outstanding domestic bonds (\% of GDP) in source & $\frac{-0.00204}{(0 * * *}$ & $-\frac{-0.00200}{(0)^{* *}}$ & $\begin{array}{c}-0.00190 \\
(0)^{* * *}\end{array}$ & $\begin{array}{c}-0.00166 \\
(0)^{* * *}\end{array}$ & $\begin{array}{l}-0.00281 \\
(0)^{* * *}\end{array}$ & $\begin{array}{c}-0.00723 \\
(0)^{* * *}\end{array}$ & $\begin{array}{c}-0.00584 \\
\left(1.40 \mathrm{e}-066^{* * *}\right.\end{array}$ & $\begin{array}{l}-0.00478 \\
(0)^{* * *}\end{array}$ & $\begin{array}{l}-0.00705 \\
(0 * * * *\end{array}$ & $\begin{array}{c}-0.00748 \\
(0)^{* * *}\end{array}$ \\
\hline Stock market capitalization or outstanding domestic bonds (\% of GDP) in destination & $\begin{array}{c}0.000376 \\
(0.00141)^{* \star *}\end{array}$ & $=\frac{-5.06 \mathrm{e}-05}{(0.772)}$ & $\begin{array}{c}0.000430 \\
(0.000348)^{* * *}\end{array}$ & $\begin{array}{c}-4.51 \mathrm{e}-05 \\
(0.473)\end{array}$ & $\begin{array}{c}0.00201 \\
(0)^{\star * \star}\end{array}$ & $\begin{array}{c}-0.00286 \\
(1.48 \mathrm{e}-06)^{* \star *}\end{array}$ & $\begin{array}{l}0.00123 \\
(0.364)\end{array}$ & $\begin{array}{c}-0.00293 \\
(0)^{* \star \star}\end{array}$ & $\begin{array}{c}-0.00201 \\
(0.000104)^{\star \star \star *}\end{array}$ & $\begin{array}{c}-0.00444 \\
(3.35 e-10)^{\star \star \star}\end{array}$ \\
\hline Inflow or outflow restrictions in source & $\begin{array}{c}-0.107 \\
(1.18 \mathrm{e}-05)^{\star \star \star \star}\end{array}$ & $\begin{array}{l}0.0468 \\
(0.109)\end{array}$ & $\begin{array}{c}-0.0766 \\
(0.00181)^{\star * *}\end{array}$ & $\begin{array}{l}-0.0565 \\
(0)^{* * *}\end{array}$ & $\begin{array}{c}-0.0548 \\
(0.0511)^{*}\end{array}$ & $\begin{array}{l}-0.685 \\
(0)^{* * *}\end{array}$ & $\begin{array}{l}-0.0380 \\
(0.811)\end{array}$ & $\begin{array}{l}-0.407 \\
(0)^{* * *}\end{array}$ & $\begin{array}{l}0.245 \\
(0)^{* * *}\end{array}$ & $\begin{array}{l}-0.727 \\
(0)^{* * *}\end{array}$ \\
\hline Inflow or outflow restrictions in destination & $\begin{array}{l}-0.0448 \\
\left(0.02499^{* *}\right.\end{array}$ & $\begin{array}{c}-0.0824 \\
(0.0178)^{* \star}\end{array}$ & $\begin{array}{l}-0.0471 \\
(0.0186)^{* *}\end{array}$ & 0.0283 & $\begin{array}{l}-0.0547 \\
0.0177 * *\end{array}$ & -0.711 & -0.0541 & -0.421 & 0.0951 & $\begin{array}{l}-0.909 \\
0(0 * * *\end{array}$ \\
\hline Governance in source & $\begin{array}{l}0.218 \\
(0)^{* * \star}\end{array}$ & $\begin{array}{c}-0.139 \\
(9.69 \mathrm{e}-07)^{\star \star * *}\end{array}$ & $\begin{array}{c}0.241 \\
(0)^{* \star \star}\end{array}$ & $\begin{array}{l}0.261 \\
(0)^{* * \star}\end{array}$ & $\begin{array}{l}0.214 \\
(0)^{\star * \star}\end{array}$ & $\begin{array}{l}0.136 \\
(0)^{* * *}\end{array}$ & $\begin{array}{c}0.186 \\
(0.00271)^{\star \star *}\end{array}$ & $\begin{array}{l}0.293 \\
(0)^{* * \star}\end{array}$ & $\begin{array}{c}0.111 \\
(3.52 \mathrm{e}-09)^{\star \star \star *}\end{array}$ & $\begin{array}{l}0.147 \\
(0)^{* * *}\end{array}$ \\
\hline Governance in destination & $\begin{array}{l}0.111 \\
(0)^{* * *}\end{array}$ & $\begin{array}{l}-0.0294 \\
(0.286)\end{array}$ & $\begin{array}{l}0.123 \\
(0)^{* * *}\end{array}$ & $\begin{array}{l}0.0430 \\
(0)^{* * *}\end{array}$ & $\begin{array}{l}0.0660 \\
(0)^{* * *}\end{array}$ & $\begin{array}{l}0.157 \\
(0)^{* * *}\end{array}$ & $\begin{array}{c}0.182 \\
(0.00162)^{* \star *}\end{array}$ & $\begin{array}{l}0.204 \\
(0)^{* * *}\end{array}$ & $\begin{array}{l}0.226 \\
(0)^{* * *}\end{array}$ & $\begin{array}{c}0.128 \\
(1.28 \mathrm{e}-10)^{* * *}\end{array}$ \\
\hline Bilateral trade (\% of destination GDP) & $\begin{array}{l}0.0394 \\
(0)^{* * *}\end{array}$ & $\begin{array}{l}0.0438 \\
(0)^{* \star \star}\end{array}$ & $\begin{array}{l}0.0289 \\
(0)^{* * *}\end{array}$ & $\begin{array}{c}0.0463 \\
(0)^{* * *}\end{array}$ & $\begin{array}{l}0.0306 \\
(0)^{* * *}\end{array}$ & $\begin{array}{l}0.0583 \\
(0)^{\star * \star}\end{array}$ & $\begin{array}{c}0.0396 \\
(7.95 \mathrm{e}-08)^{* \star *}\end{array}$ & $\begin{array}{l}0.0523 \\
(0)^{* \star \star}\end{array}$ & $\begin{array}{c}0.0407 \\
(2.61 \mathrm{e}-07)^{* * *}\end{array}$ & $\begin{array}{l}0.118 \\
(0)^{* * *}\end{array}$ \\
\hline Log distance & $\begin{array}{l}-0.353 \\
(0)^{*+*}\end{array}$ & $\begin{array}{l}-0.401 \\
(0)^{*+*}\end{array}$ & $\begin{array}{l}-0.408 \\
(0)^{* * * *}\end{array}$ & $\begin{array}{l}-0.218 \\
(0)^{* * *}\end{array}$ & $\begin{array}{l}-0.321 \\
(0)^{*+*}\end{array}$ & $\begin{array}{l}-0.826 \\
(0)^{* * *}\end{array}$ & $\begin{array}{l}-0.773 \\
(0)^{* * *}\end{array}$ & $\begin{array}{l}-0.620 \\
(0)^{* * *}\end{array}$ & $\begin{array}{l}-0.749 \\
(0)^{* * *}\end{array}$ & $\begin{array}{l}-0.762 \\
(0)^{* * *}\end{array}$ \\
\hline Stock market return or bond yield in source & $: 0.0104$ & $\begin{array}{c}0.0232 \\
\left(0.004033^{* \star *}\right.\end{array}$ & & $\begin{array}{c}0.0268 \\
\left(4.96 \mathrm{e}-055^{\star * * *}\right.\end{array}$ & $\begin{array}{l}0.00802 \\
(0.310)\end{array}$ & $\begin{array}{l}-0.145 \\
(0) * * *\end{array}$ & $\begin{array}{c}-0.0804 \\
\left(4.45-088^{* * *}\right.\end{array}$ & & $\begin{array}{l}-0.126 \\
(0)^{* * *}\end{array}$ & $\begin{array}{l}-0.150 \\
(0)^{* * *}\end{array}$ \\
\hline Stock market return or bond yield in destination & $\begin{array}{c}0.0164 \\
(0.00849)^{* \star *}\end{array}$ & $\begin{array}{l}-0.00163 \\
(0.798)\end{array}$ & & $\begin{array}{c}0.0127 \\
(0.00493)^{* \star *}\end{array}$ & $\begin{array}{c}0.0279 \\
(8.50 \mathrm{e}-05)^{\star \star *}\end{array}$ & $\begin{array}{l}0.0496 \\
(0)^{* * *}\end{array}$ & $\begin{array}{l}0.00216 \\
(0.802)\end{array}$ & & $\begin{array}{l}0.0618 \\
(0)^{* \star *}\end{array}$ & $\begin{array}{c}0.0306 \\
(0.000355)^{\star \star \star}\end{array}$ \\
\hline Correlation in stock market returns or sovereign bond yields & $\begin{array}{l}0.359 \\
(0)^{* * *}\end{array}$ & $\begin{array}{l}0.0858 \\
(0.0152)^{* *}\end{array}$ & & $\begin{array}{l}0.397 \\
(0)^{* *+}\end{array}$ & $\begin{array}{l}0.292 \\
(0)^{* * *}\end{array}$ & $\left(\begin{array}{c}0.114 \\
(1.76 \mathrm{e}-08)^{* * *}\end{array}\right.$ & $\begin{array}{c}0.0732 \\
\left(5.22-055^{* \star * *}\right.\end{array}$ & & $\begin{array}{l}0.142 \\
(0)^{* * *}\end{array}$ & $\begin{array}{c}0.122 \\
(1.64 \mathrm{e}-07)^{\star \star \star \star}\end{array}$ \\
\hline Constant & $\begin{array}{l}2.658 \\
(0)^{* * *}\end{array}$ & $\begin{array}{l}9.146 \\
(0)^{* * *}\end{array}$ & $\begin{array}{l}3.213 \\
(0)^{* * *}\end{array}$ & $\begin{array}{l}1.400 \\
(0)^{* * *}\end{array}$ & $\begin{array}{l}2.373 \\
(0)^{* * *}\end{array}$ & $\begin{array}{l}8.613 \\
(0)^{* * *}\end{array}$ & $\begin{array}{l}12.45 \\
(0)^{* * *}\end{array}$ & $\begin{array}{l}5.752 \\
(0)^{* * *}\end{array}$ & $\begin{array}{l}6.565 \\
(0)^{* * *}\end{array}$ & $\begin{array}{l}8.379 \\
(0)^{* * *}\end{array}$ \\
\hline Observations & 8,382 & 8,382 & 8,508 & 8,142 & 7,632 & 4,278 & 4,278 & 5,964 & 4,278 & 3,840 \\
\hline Number of node12code & 1,397 & 1,397 & 1,418 & 1,357 & 1,272 & 713 & 713 & 994 & 713 & 640 \\
\hline Wald statistic & 5549 & 6686 & 5576 & 6167 & 3773 & 3229 & 7408 & 3465 & 2850 & 2978 \\
\hline $\begin{array}{l}\text { pval in parentheses } \\
{ }_{* \star *} p<0.01,{ }^{* *} p<0.05,{ }^{*} p<0.1\end{array}$ & & & & & & & & & & \\
\hline Note: Regression includes time fixed effects. & & & & & & & & & & \\
\hline
\end{tabular}


Table 7. Impact of hypothetical capital account liberalization in China on gross portfolio investment, 2010 (percent of GDP)

\begin{tabular}{|c|c|c|c|c|c|}
\hline & $\begin{array}{r}\text { Regressions } \\
\text { Tables } 3 \text { and } 6 \\
\end{array}$ & $\begin{array}{r}\text { Regressions } \\
\text { Tables } 3 \text { and } 6 \\
\text { using adjusted } \\
\text { markets }\end{array}$ & $\begin{array}{r}\text { He et al } \\
(2012) \\
\end{array}$ & $\begin{array}{r}\text { Sedik and } \\
\text { Sun (2012) } \\
1 /\end{array}$ & $\begin{array}{r}\text { Actual } \\
\text { stock, end- } \\
2010 \\
\end{array}$ \\
\hline Equity assets & 2.6-7.3 & $1.9-5.3$ & $\ldots$ & $\ldots$ & 1.1 \\
\hline Equity liabilities & $0.3-0.4$ & $0.3-0.4$ & $\ldots$ & $\ldots$ & 3.5 \\
\hline Debt assets & $10.5-21$ & $6-12$ & $\ldots$ & $\ldots$ & 3.3 \\
\hline Debt liabilities & $1.3-9.5$ & $1.3-9.5$ & $\ldots$ & $\ldots$ & 0.3 \\
\hline Portfolio assets & $15.4-24.9$ & $9.4-15.1$ & 21.0 & 3.3 & 4.3 \\
\hline Portfolio liabilities & $1.7-9.9$ & $1.7-9.9$ & 16.0 & 2.0 & 3.8 \\
\hline Net portfolio assets & $10.7-18.1$ & $4.1-8.2$ & 5.0 & 1.3 & 0.6 \\
\hline
\end{tabular}

1/ Applies to total capital inflows and outflows. 


\section{REFERENCES}

Bayoumi, Tamim, and Christian Saborowski, 2012, “Accounting for Reserves," IMF Working Paper 12/302 (Washington: International Monetary Fund).

Benelli, Roberto, 2011, "Potential Impact on Global Bond Markets of Reallocating Reserves," China: Spillover Report for the 2011 Article IV Consultation and Selected Issues, (Washington: International Monetary Fund).

Bertaut, Carol, and Linda Kole, 2004, "What Makes Investors Over or Underweight? Explaining International Appetites for Foreign Equities," International Financial Discussion Papers No. 819. Board of Governors of the Federal Reserve System.

Chinn, Menzie D., and Hiro Ito, 2008, “A New Measure of Financial Openness,” Journal of Comparative Policy Analysis, Volume 10, Issue 3, pp. 309-22 (September).

Eichengreen, Barry, 2001, “Capital Account Liberalization: What Do Cross-Country Studies Tell Us?” World Bank Economic Review, Vol. 15, No. 3, pp. 341-65, (Washington).

Fischer, S., 1998, "Capital-Account Liberalization and the Role of the IMF," in "Should the IMF Pursue Capital-Account Convertibility?" ed. by P. Kenen, Princeton Essay in International Finance, No. 207.

Forbes, Kristin, 2010, "Why Do Foreigners Invest in the Unites States?” Journal of International Economics, Vol. 80, No. 1, pp. 3-21.

Groombridge, Mark, 2001, "Capital Account Liberalization in China: Prospects, Prerequisites, and Pitfalls," Cato Journal, Vol. 21, No. 1, pp. 119-31.

Guo, Kai, 2011, “China's Closed Capital Account and Capital Flows to Emerging Markets," China: Spillover Report for the 2011 Article IV Consultation and Selected Issues (Washington: International Monetary Fund).

Guonan, Ma, and Robert McCauley, 2003, “Opening China's Capital Account Amid Ample Dollar Liquidity,” BIS Papers chapters, in: Bank for International Settlements, China's Capital Account Liberalization: International Perspective, Vol. 15, pp. 2534, (Bank for International Settlements. ed.).

He, Dong, Cheung, Lillian, Zhang, Wenlang, and Wu, Tommy T., 2012, "How Would Capital Account Liberalization Affect China's Capital Flows and the Renminbi Real Exchange Rates?" China and the World Economy, Vol. 20, No. 6, pp. 29-54. 
Harding, D., and A. Pagan, 2002, "Dissecting the Cycle: A Methodological Investigation," Journal of Monetary Economics, Vol. 49, pp. 365-81.

Kaminsky, Graciela, and Sergio Schmukler, 2003, "Short-Run Pain, Long-Run Gain: The Effects of Financial Liberalization,” NBER Working Papers No. 9787.

Lane, Philip, and Gian Maria Milesi-Ferretti, 2008, "International Investment Patterns," Review of Economics and Statistics No. 90 (3), pp. 538-49.

Lardy, Nicholas, and Patrick Douglas, 2011, "Capital Account Liberalization and the Role of the Renminbi," Peterson Institute for International Economics Working Paper No. 116 (February 23).

Li, Dongping, 2008, "Mis-invoicing in Trade Transaction of China and its Effects on Monetary Policy in Recent Years," International Economic Review, Vol.3, pp. 1-15.

Mei, Jianping, Jose A. Scheinkman, and Wei Xiong, 2009, "Speculative Trading and Stock Prices: Evidence from Chinese A-B Share Premia," Annals of Economics and Finance, Vol. 10, No. 2, pp. 225-55.

Prasad, Eswar, and Raghuram Rajan, 2008, "A Pragmatic Approach to Capital Account Liberalization,” Journal of Economic Perspectives, Vol. 22, No. 3, pp. 149-72.

Quinn, Dennis P., 2003, "Capital Account Liberalization and Financial Globalization, 18901999," International Journal of Finance and Economics, 8 (July) pp. 189-204.

Rodlauer, Markus, and Papa N'Diaye, 2013, eds., "IMF and PBC Joint Conference on

Capital Flows Management: Lessons from International Experience," International Monetary Fund and People's Bank of China.

Sedik, Saadi Tahsin, and Sun, Tao, 2012, "Effects of Capital Flow Liberalization—What is the Evidence from Recent Experiences of Emerging Market Economies? (November) IMF Working Paper 12/275 (Washington).

Schindler, Martin, 2009, "Measuring Financial Integration: A New Data Set," IMF Staff Paper, Vol. 56, No. 1, pp. 222-38 (Washington).

Taylor, Mark, and M. J Artis, 1989, "U.K. Exchange Controls: Effects of Abolition,” CEPR Discussion Paper No. 294. 
Yan, May; Mimi Kong; and Sean Hung, 2013, "Containing China's Wealth Management Market and Impacts on the Financial System—Revisiting the Key Issues," Barclays Equity Research. 